\title{
Practice report: Sustainability impact assessment in Hong Kong and the Pearl River Delta: "both necessary and impossible”?
}

\author{
Mee Kam Ng and Dennis Lai Hang Hui
}

\begin{abstract}
Rapid economic integration of Hong Kong and the Pearl River Delta under the policy of "One Country Two Systems" and the consequent social and environmental degradation mean that assessment of sustainability impacts of development projects is essential. However, some fundamental problems are identified for the two systems to carry out SIA before embarking on development projects: minimal integration in terms of institutional set-up, strategies and policies concerning sustainable development; pre-set sustainability indicators rather than tailor-made ones to assess policies, programmes and projects of various nature; and rather different social, economic and environmental norms and development problems. In the short run, given these constraints, SIA in the region though "necessary" is rather "impossible". Nevertheless, recommendations are put forward to facilitate regional cooperation of SIA practices in the longer term.
\end{abstract}

Keywords: Hong Kong, Pearl River Delta, sustainability impact assessment

$\mathrm{P}$ OSSIBILITIES AND EFFECTIVENESS of transboundary sustainability impact assessment (SIA) hinge on how the processes are institutionalised in specific socio-economic and political contexts. This paper outlines briefly a synthesised SIA framework that is then used to review the current state of play of SIA in Hong Kong and the Pearl River Delta, two systems under one country. It identifies how existing institutional set-up hampers the effectiveness of SIA. Recommendations are put forward to facilitate the eventual realisation of SIA in the region.

\section{SIA: a synthesised framework}

As noted by Buselich (2002: 1), SIA is:

\footnotetext{
Mee Kam Ng is Associate Professor and Dennis Lai Hang Hui is a PhD candidate, Centre of Urban Planning and Environmental Management, The University of Hong Kong, Hong Kong, PRC; Emails: meekng@hku.hk; valance@hku.hk.
}

needed to address the economic, social and environmental interdependencies within policies, plans, legislation and projects ... to assess the cumulative and synergistic impacts of decisions and management practice ... [to] facilitate ... greater certainty, transparency and accountability of government decision-making processes and enable a more inclusive and informed decision-making.

The underlying rationale of SIA is that policymaking has to attend to the degree of resource utilisation of development initiatives and whether they may enhance or compromise the carrying, absorptive and assimilative capacity of interrelated socioeconomic and environmental domains. This means that SIA is a highly context-dependent exercise. Whether SIA is fully integrated with the policy or project cycle and affects strategic decision-making depends a lot on the institutional set-up of a place.

However, as Pierson (2000) argues, political institution is change-resistant. This explains why SIA is yet to be widely applied because the practice 


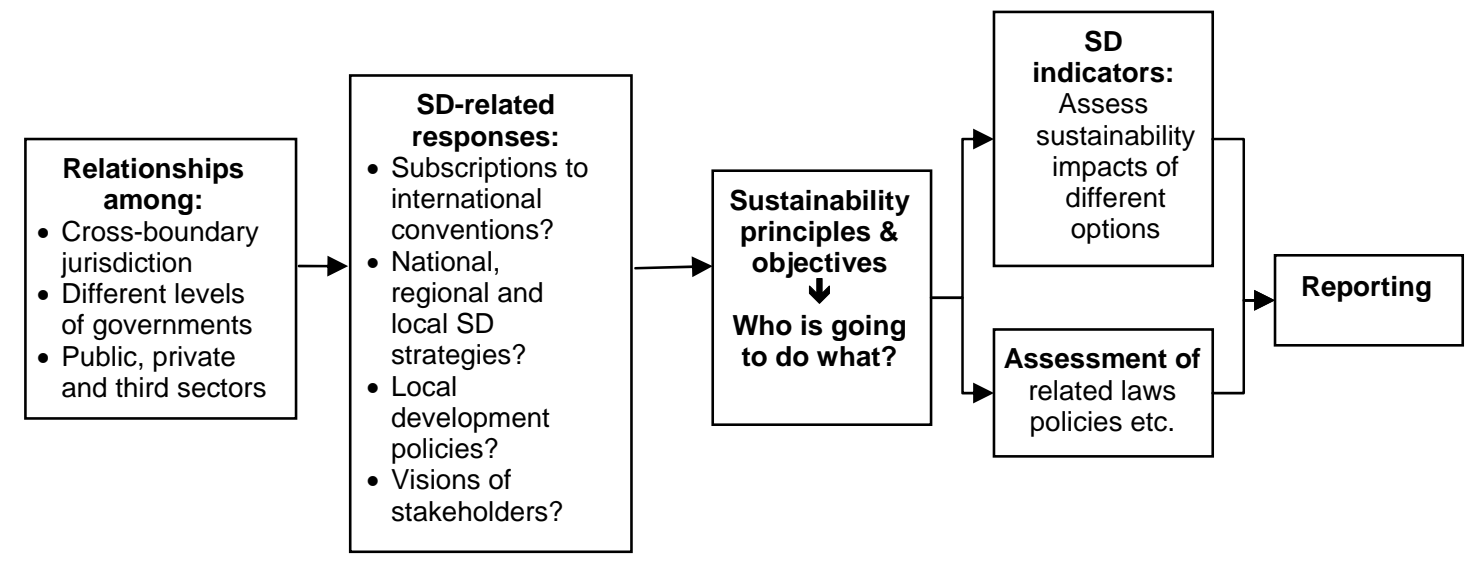

Figure 1. SIA framework

Source: Authors, synthesised from Buselich (2002), ODPM (2003), Dalal-Clayton and Sadler (2004) and SAGIG (2005)

challenges directly compartmentalised policymaking within and between different levels of governments. The following SIA framework (Figure 1) is synthesised to facilitate a systematic review of the institutional resources available for and the problems of conducting SIA in the transboundary region of Hong Kong and the Pearl River Delta (PRD).

\section{SIA in China and Hong Kong}

In Hong Kong, a Computer-aided Sustainability Evaluation Tool (CASET) was designed in the absence of a city-wide sustainable development strategy. Instead of having sustainability targets tallying with international conventions related to sustainable development, CASET only offers a standard list of indicators for policy-makers or project proponents to assess sustainability impacts. Across the administrative boundary in the Pearl River Delta where thousands of Hong Kong factory owners are employing millions of workers, development, at least in rhetoric, is informed by China's Agenda 21 (PRC, 1994) and the regional sustainable development strategy in Guangdong. With intensified economic and spatial integration and consequent social and environmental degradation in the region, an SIA framework is necessary to ensure the long-term sustainability of the region.

\section{Sustainability impact assessment is necessary ${ }^{1}$}

While China is among the pioneering countries to produce a national Agenda 21 (PRC, 1994) and developed a national sustainable development strategy in 1994, and Guangdong produced in 1997 a Study Report on the Implementation of China's Agenda 21 for Guangdong Province, SIA is not standard practice in Guangdong in general and in the PRD in particular. Economic growth, rather than sustainable development, is the primary concern of local authorities.

The PRD occupies only one quarter of the land area in Guangdong and has 57\% of the province's population. However, the Delta accounts for $79 \%$ of the province's gross domestic product (GDP), about $95.2 \%$ of its exports and $90 \%$ of GDP actually used (GDSB, 2002; HKTDC, 2002). Growth is the order of the day in the Delta. Housing a population of 42.89 million, ${ }^{2}$ the Delta is not only a world factory but also a huge consumption market (per capita annual income is US\$3,800). Table 1 represents some key statistics of the PRD.

The socio-economic linkages between Hong Kong and the PRD are substantial. The majority of the Chinese population in Hong Kong have their roots in the PRD. Economically speaking, about $90 \%$ of Hong Kong manufacturers have production facilities in the PRD. In some 65,000 factories, Hong Kong investors employ about six million workers (some reported over 10 million) in the Delta (HKTDC, 2002). Over $80 \%$ of Hong Kong traders source from the PRD and Hong Kong handles about $80 \%$ of the PRD's imports and exports (HKTDC, 2002).

The substantial socio-economic linkages imply that sustainability issues cannot be contained in the respective administrative boundary. The adoption of the Open Door Policy in the late 1970s triggered a

Table 1. Key statistics of the Pearl River Delta

\begin{tabular}{|c|c|c|c|c|}
\hline \multirow{2}{*}{$\begin{array}{l}\text { Profile } \\
\text { Area }\end{array}$} & \multirow{2}{*}{$\begin{array}{c}\begin{array}{c}\% \text { of } \\
\text { China }^{\mathrm{c}}\end{array} \\
0.4\end{array}$} & \multirow{2}{*}{$\begin{array}{c}\begin{array}{c}\% \text { of } \\
\text { GDP }^{d}\end{array} \\
25.0\end{array}$} & \multicolumn{2}{|c|}{$\begin{array}{l}\text { Achievements (average } \\
\text { growth 1996-2001) }\end{array}$} \\
\hline & & & GDP & $+13.3 \%$ \\
\hline Population & 3.3 & 56.7 & Export value & $+12.2 \%$ \\
\hline $\mathrm{GDP}^{\mathrm{a}}$ & 8.7 & 78.9 & Import value & $+10.8 \%$ \\
\hline Export value ${ }^{a}$ & 34.0 & 95.2 & FDI & $+7.0 \%$ \\
\hline Import value ${ }^{a}$ & 32.0 & 95.8 & Retail sales & $+12.3 \%$ \\
\hline $\begin{array}{l}\text { Foreign direct } \\
\text { investment }^{\mathrm{b}}\end{array}$ & 24.0 & 90.1 & $\begin{array}{l}\text { Fixed assets } \\
\text { investment }\end{array}$ & $+10.0 \%$ \\
\hline $\begin{array}{l}{ }^{\mathrm{a}} \mathrm{a} \\
{ }^{\mathrm{b}} \mathrm{1} \\
{ }^{\mathrm{c}} \mathrm{F} \\
{ }^{\mathrm{d}} \mathrm{F} \\
{ }^{\mathrm{F}} \mathrm{F}\end{array}$ & $\begin{array}{l}001 \\
2001 \\
\text { s fror } \\
\text { s fror } \\
4)\end{array}$ & DC & 02) & (20) \\
\hline
\end{tabular}


twinning process in which Hong Kong shed its low value-added manufacturing processes to the Delta and moved towards a service-sector oriented economy. The exodus of labour-intensive and low valueadded industries have quickened and deepened the economic restructuring process in Hong Kong, with serious spatial, socio-economic and political consequences (Ng, 2002: 286).

In the PRD, urban areas have increased by more than 300\% between 1988 and 1996 (Seto et al, 2002) and the availability of job opportunities has attracted numerous migrant workers from inner provinces. The mushrooming of industries all over the PRD has led to various socio-economic, environmental and spatial problems. Table 2 highlights some of the most obvious socio-economic and environmental issues in the process of regional development.

Given the growth mentality, the development issues identified are not tackled with determination by the local governments. Even if there is a will to tackle these regional problems, administratively Hong Kong is separated from the rest of the PRD under the arrangement of the 'one country, two systems' concept. Furthermore, the Pearl River Delta is a region composed of many administrative units (one provincial capital, two special economic zones, two special administrative regions, nine prefectural cities, 13 county-level cities, 27 district governments and numerous towns and neighbourhoods); this is a real challenge for the multi-dimensional integration required for SIA practices.
Unless there is an institutional capacity to conduct sustainability impact assessment of planning proposals and projects, uncoordinated and frenetic developments in the Delta would eventually stifle growth and threaten the sustainability of long-term economic growth. On the mainland, although the PRD Urban System Plan used sustainable development as a planning principle, it has few teeth in terms of implementation (Ng and Tang, 1999). Development has been frenetic and uncoordinated throughout the Delta areas.

\section{SIA in the Pearl River Delta}

China's Agenda 21 provides a national strategic framework for implementing sustainable development. The document also provides guiding posts for the establishment of a sustainability assessment system. The Administrative Centre for China's Agenda 21 and the State Statistics Bureau have proposed a set of 83 sustainable development indicators divided into seven categories. SIA at the central level is still at a formative stage. Guangdong Province does not have its own Agenda 21. However, it produced a Study Report on the Implementation of China's Agenda 21 for Guangdong Province in 1997. The Guangdong Province's sustainable development indicator system and assessment methods are formulated by the Development Research Centre of the Guangdong Provincial People’s Government. ${ }^{3}$

The indicator system is structured into five themes (Li and Chen, 1999):

Table 2. Socio-economic, environmental and spatial development problems in the Hong Kong-Pearl River delta region

\section{Hong Kong}

- Rapid loss of manufacturing jobs, rising unemployment and increasing social polarisation

- However, population growth resulting from immigration from China, most are for family reunion purposes because many lower class men in Hong Kong could only afford to get married in China

- The existing urban fabric and quality of human resources have become 'limits to capital'. Major regeneration is urgently required to equip the city for another round of capital accumulation

- For Hong Kong to become a knowledgebased society, we have to improve the quality of life and move towards high-tech industrial development, building on the strength as a financial centre

- However, environmental stress, visibly expressed in forms of pollution and degradation of the natural environment as a result of decades of economics-biased development, is dampening the attractiveness of Hong Kong for overseas investment
Trans-boundary

Rapid economic integration between Hong Kong and the PRD has led to many environmental, social and physical planning problems

Pollution problems in the PRD cannot be contained within the Delta itself. They have reached an alarming state and, unless concerted efforts are made soon, the region will not be sustainable in the future. Air pollution, among others, is a case in point

- Because of the discrepancy of economic developments in Hong Kong and the PRD, many social problems, such as second wives, parallel goods trading and various crime-related activities, take place

So far, the economic integration has primarily been 'market-led'. The public sector has been more proactive in fostering regional co-operation in recent years, especially in building infrastructure to overcome frictional space. However, the practice of 'one country, two systems' has introduced considerable barriers and obstacles for the region to co-operate and learn to build up trust in regional development

\section{The Pearl River Delta}

Rapid industrialisation and urbanisation have degraded the land of 'fish and rice'. Rich agricultural land has been converted to industrial uses; the natural environment has been contaminated by air, water, noise pollution; and wastes have been produced

Massive construction of infrastructure has led to environmental problems and created financial burden for local authorities

Floating population has been an issue in the Delta for decades now, which has led to all sorts of social problems

Similar to Hong Kong, different parts of the Delta have undergone various degrees of economic restructuring leading to all sorts of 'destructive creation' along with evident social polarisation

As all the local authorities would like to attract more investment, they have entered into a vicious cycle of competition and local protection, duplicating efforts and wasting resources in the race to attract foreign investment 
- magnitude of government's support for social pursuits;

- eco-environmental protection and efficient utilisation of natural resources;

- technological advancement and raising quality of human resources;

- optimising economic structure and enhancing economic efficiency;

- raising the spiritual and material quality of living.

The system has been used to assess the degree of co-ordination among the economy, society and natural resources in the Pearl River Delta. However, according to local government officials, the system is in a formative stage and they are still modifying it. $^{4}$ The indicators are used for assessing macro and aggregate performance of cities rather than individual policies or projects.

\section{SIA in Hong Kong}

Unlike the Mainland, Hong Kong does not have an Agenda 21. However, in a study on Sustainable Development in Hong Kong for the 21st Century (SUSDEV21) published in 2000, CASET was proposed to assist the Government in assessing policies (Planning Department, 2000). CASET is built on eight guiding principles and a set of 41 sustainability indicators. ${ }^{5}$ The indicators are grouped into eight key areas: economy; health and hygiene; natural resources; society and social infrastructure; biodiversity; leisure and cultural vibrancy; environmental quality; and mobility.

Government bureaux and departments are expected to use CASET to assess various policy options and development projects. However, CASET is not intended to "provide a verdict as to whether a proposal is sustainable, nor will it mandate how conflicts or trade-offs should be resolved. These challenges remain with decision-makers” (Planning Department, 2000, emphasis added). Besides CASET, Hong Kong enacted the Environmental Impact Assessment (EIA) Ordinance in 1998, which requires designated projects to go through a statutory EIA process to obtain environmental permits for project construction and operation. However, the EIA process only covers the environmental aspects.

\section{Is SIA possible in Hong Kong-PRD region?}

Several factors account for the absence of an integrated SIA framework in the Hong Kong-PRD region. Within Hong Kong, administrative rationality emphasises the role played by expert professionals and experienced government officials in the assessment process, rather than citizens and community members (Dryzek, 1997; Hills, 2004). The social and environmental aspects (except designated projects that require an environmental permit) are often neglected in the development process.
Policy-making in China also operates in a highlystratified and top-down fashion, with minimal, if any, public participation. The Chinese administration system has been gradually tightening the bureaucratic control and more performance criteria have been used to evaluate local officials (Burns, 2003). However, most of these criteria attach priority to economic growth rather than sustainable development. Limited public access to information, especially that of a sensitive nature, means that the information required for SIA would also be restricted.

In the Pearl River Delta, there is the problem of 'prefectural warlordism'. Local politicians have endeavoured to produce tangible results in their own jurisdiction in order to impress national leaders of their capability. This, however, relegates regional co-ordination to a secondary role, resulting in "unreasonable competition, duplication of construction, waste of resources and insufficient vision of regionwide thinking and planning” (Yang, 2006: 82; see also Yang, 2004: 114) and in uncoordinated market place (Hu and Chan, 2002). Any regional SIA that calls for multi-dimensional integration will be difficult as local authorities focus more on competition than co-operation (Chu et al, 2002).

The 'one country, two systems' formula for Hong Kong's reunification with China has resulted in a lack of integration and opportunities to have mutual learning of one another's institutional set-up and culture among the various local authorities in the region. Minimal institutional integration coupled with a competitive growth mentality in the region present major barriers to the formulation of a commensurate SIA framework in the region. ${ }^{6}$ Currently, any political interactions between Hong Kong and the various governments in mainland China have to pass through, and obtain the approval from, the relevant departments in the Central Authority, such as the Office of Hong Kong and Macau Affairs (Yang, 2006).

Nevertheless, several regional co-operation mechanisms have been launched, including current infrastructural projects, economic development and infectious disease control and surveillance. On sustainability-related issues, an environmental working group was set up between Guangdong and Hong Kong that has Government officials as representatives from both sides (Hills and Roberts, 2001). However, this working group is issue-driven and "never progressed beyond a forum for discussion" (Hills and Roberts, 2001: 466).

\section{The way forward}

Rapid economic integration in the Pearl River Delta and the consequent need for infrastructure development have constantly exerted socio-economic and environmental impacts and challenged the often incompatible institutionalised mechanisms developed in various localities in the course of planning and development. To maintain its long-term sustainability 
and competitiveness, SIA is necessary in the PRD. However, the minimal integration of jurisdictions on both sides of the administrative boundary and the different institutional set-up created by their drastic‘ally varied development trajectories have presented tremendous difficulties in developing a regionally integrated SIA framework.

The prospect of developing an integrated SIA framework within Hong Kong or the PRD in the short term is also not particularly encouraging. Given the predominance of administrative rationality in the executive-led Government of Hong Kong and the city's economics-first mentality that favours market-driven developments, it is not very likely that the city will commit itself to international conventions related to sustainable development or implement a serious sustainable development strategy that will be backed up by policies and legal instruments.

Hong Kong needs to be more proactive in mapping out her role in relation to global sustainability issues and developing her responses at the local level. While the CASET offers a set of useful principles and indicators, they would have more teeth in driving sustainability of Hong Kong forward had they been derived from commitment to international protocols and been backed up with integrated strategies and policies detailing a clear division of labour within and among the public, private and third sectors in the course of assessing policies, programmes or projects.

Unlike Hong Kong, the PRD, as a result of China's commitment to many international conventions and the national and regional sustainable development strategies, already has a set of principles and indicators that can be used for SIA. The problem

\section{Notes}

1. Extracted from $\mathrm{Ng}$ (2006: 317-327).

2. Population recorded in the Fifth National Population Census which adopted a de jure method (usual residents) and used midnight on 1 November 2000 as the reference time.

3. See Li and Chen (1999: 13) for the original Chinese version and $\mathrm{Ng}$ (2005: 323) for an English translation.

4. Telephone interview conducted in 2002.

5. CASET principles are available at <http://www.susdev.gov.hk/ $\mathrm{html} / \mathrm{en} / \mathrm{su} /$ GuidingPrinciples_e.pdf> (last accessed 10 July 2006) and indicators at <http://www.susdev.gov.hk/ $\mathrm{html} / \mathrm{en} / \mathrm{su} /$ SustainabilityIndicators e.pdf> (last accessed 10 July 2006).

6. A commensurate SIA framework is desirable for mutual understanding and to boost the relevance and validity of the assessment results especially when local authorities are adopting rather different socio-economic and environmental standards in monitoring their urban conditions.

\section{References}

Burns, J P 2003. Governance and public sector reform in the People's Republic of China. In Governance and Public Sector Reform in Asia, eds. A B L Cheung and I Scott, pp. 67-89. London: RoutledgeCurzon. is that, being a transitional economy still struggling to leave behind central planning to become a socialist market economy, sustainable development has a different meaning in China. Instead of being a path to ameliorate the wrongs of industrial capitalism, sustainable development in China is interpreted as a means to hasten the transition of its economy into a market-driven one (Ng, 2005). Economic growth is, according to the Chinese Government, at the heart of sustainable development, and social and environmental sustainability cannot be achieved without “rapid economic growth” (Ng et al, 2003).

This mentality and the subsequent institutional set-up will not be conducive to serious SIA practices. In the longer term, local authorities and stakeholders have to reflect on their understanding of sustainable development and establish effective institutional mechanisms that take SIA seriously.

Both Hong Kong and the PRD would need to commit to sustainable-development related international conventions, harmonise their development strategies to achieve a version of sustainable development agreeable to local authorities and formulate respective local strategies and policies. By so doing, various sectors can be mobilised to agree on sustainable development principles, objectives and sustainability indicators to assess impacts of proposed policies or projects. This probably will not take place in the short term. In the meantime, Hong Kong and the PRD should agree on a set of sustainability principles and identify appropriate indicators to assess policies and projects having regional implications. The current absence of such a practice is lamentable and is definitely detrimental to the competitiveness and sustainability of the region as a whole.

Buselich, K 2002. An outline of current thinking on sustainability assessment. Background paper prepared for the Western Australian State Sustainability Strategy. Available at <http://www.sustainability.dpc.wa.gov.au/BGPapers/ KathrynBuselichSustainabilityAssessment.pdf>, last accessed 10 July 2006

Chan, R C K 1998. Cross-border regional development in Southern China. GeoJournal, 44(3), 225-237.

Chu, D K Y, J Shen and K-Y Wong 2002. Shenzhen-Hong Kong as one: modes and prospectus of regional governance in the Pearl River Delta. In Resource Management, Urbanization and Governance in Hong Kong and the Zhujiang Delta, eds. K-Y Wong and J Shen, pp. 231-248. Hong Kong: The Chinese University Press.

Dalal-Clayton, B and B Sadler 2004. Sustainability Appraisal: a Review of International Experience and Practice, First Draft of Work in Progress. Available at <http://www.iied.org/Gov/spa/ docs.html >, last accessed 10 July 2006.

Dryzek, J S 1997. The Politics of the Earth: Environmental Discourses. Oxford: Oxford University Press.

GDSB, Guangdong Statistics Bureau 2002. Guangdong Statistical Yearbook 2001. Beijing: China Statistics Press.

Hills, P 2004. Administrative rationalism, sustainable development and the politics of environmental discourse in Hong Kong. In Sustainable Development in Hong Kong, ed. T Mottershead, pp. 13-42. Hong Kong: Hong Kong University Press.

Hills, P and P Roberts 2001. Political integration, trans-boundary pollution and sustainability: challenges for environmental policy in the Pearl River Delta Region. Journal of Environmental Planning and Management, 44(4), 455-473. 
HKTDC, Hong Kong Trade Development Council 2002. The Pearl River Delta: production basin and emerging market. Available at <http://www.hktrader.net/common/PRD_intro.htm>, last accessed 10 July 2006

$\mathrm{Hu}, \mathrm{Y}$ and R Chan 2002. Globalization, governance, and development of Pearl River Delta region. The China Review, 2(1), 61-83.

Li, C and J Chen 1999. Guangdong Province's sustainable development indicator system and assessment method study. Unpublished document, Development Research, Centre of the Guangdong Provincial People's Government (in Chinese).

Ng, M K 2002. The Pearl River Delta region: 'Our economic space, our life space'. In Building a Competitive Pearl River Delta Region, eds. A G O Yeh, Y S F Lee, T Lee and N D Sze, pp. 282-297. Hong Kong: Centre of Urban Planning and Environmental Management.

$\mathrm{Ng}, \mathrm{M} \mathrm{K} 2005$. Quality of life perceptions and directions for urban regeneration in Hong Kong. Social Indicators Research, 71, 441-465.

$\mathrm{Ng}, \mathrm{M}$ K 2006. Sustainability impact assessment in the Pearl River Delta region: problems and possibilities. In Developing a Competitive Pearl River Delta in South China under One Country-Two Systems, eds. A Yeh, V Sit, G Chen and Y Zhou, pp. 309-333. Hong Kong: Hong Kong University Press.

$\mathrm{Ng}, \mathrm{M} \mathrm{K}$ and W-S Tang 1999. Urban system planning in China: a case study of the Pearl River Delta. Urban Geography, 20(7), 591-616.

$\mathrm{Ng}, \mathrm{M} \mathrm{K}, \mathrm{K}$ Chan and $\mathrm{P}$ Hills 2003. Sustainable development in
China: from knowledge to action. International Journal of Environment and Sustainable Development, 2, 36-61.

ODPM, Office of the Deputy Prime Minister 2003. Strategic Environmental Assessment Directive: Guidance for Planning Authorities. London: ODPM.

Pierson $P$ 2000. Increasing returns, path dependence, and the study of politics. The American Political Science Review, 94(2), 251-267.

Planning Department 2000. Sustainable Development for the $21^{\text {st }}$ Century: Final Report. Hong Kong: Planning Department.

PRC, People's Republic of China 1994. China's Agenda 21: White Paper on China's Population, Environment, and Development in the $21^{\text {st }}$ Century. Available at <http://www.acca21. org.cn/indexe6.html>, last accessed 10 July 2006.

SAGIG, South Australian Government Inter-agency Group 2005. Development of Triple Bottom Line Assessment Methodologies. Report of a South Australian Government Inter-Agency Group.

Seto, K C, C E Woodcock, C Song, X Huang, J Lu and R K Kaufmann 2002. Monitoring land-use change in the Pearl River Delta using Landsat TM. International Journal of Remote Sensing, 23(10), 1958-2004.

Yang, C 2004. From market-led to institution-based economic integration: the case of the Pearl River Delta and Hong Kong. Issue and Studies, 40(2), 79-118.

Yang, C 2006. The Pearl River Delta and Hong Kong: an evolving cross-boundary region under 'one country, two systems'. Habitat International, 30, 61-86. 
Copyright of Impact Assessment \& Project Appraisal is the property of Beech Tree Publishing and its content may not be copied or emailed to multiple sites or posted to a listserv without the copyright holder's express written permission. However, users may print, download, or email articles for individual use. 